\title{
Intra-Abdominal Hydatidosis: Hydatid Cyst Related to Right Hepatic Colon Lumen
}

\author{
Bircan Alan ${ }^{1}$, Murat Kapan ${ }^{2}$,Hıdır Budak², Hekim Kuzu ${ }^{2}$
}

\begin{abstract}
Hydatid disease is very common in endemic areas and is one of the most frequent parasitoses in Turkey. We present a rare case of hydatidosis related to the right hepatic colon lumen. Hydatid cysts were present on the liver, in the right adrenal region, and also on the hepatic flexura, surrounded by the right colon and omentum. In our case, a cyst adjacent to the ascending colon had ruptured into the colon lumen and developed a cystocolonic communication. Cysts may not always be detectable by ultrasound (US); adrenal and right colonic cysts may not be detected, depending on the patient's colonic gas superposition factors or other reasons related to the operator. In our case, multiple hydatid cysts and cystocolonic communication of complications of the cyst were found with multidetector computerized tomography (MDCT), and then, a colonoscopy identified the cystocolonic communication. These results reveal the important role of CT in the differential diagnosis process. J Clin Exp Invest 2016; 7 (2): 207-210
\end{abstract}

Key words: Cyst hydatic, multidetector computerized tomography, ultrasound, cystocolonic communication

\section{Karın İçi Hidatidozis: Să̆ Hepatik Kolon Lumeni ile İlişkili Kist Hidatik}

\section{ÖZET}

Hidatik hastalık endemik olan yerlerde önemli sağlık sorunlarından birini oluşturmaktadır, Türkiyede de en sık görülen parazitozlardan biridir. Özellikle sağ kolona rüptür ve sekonder enfeksiyon komplikasyonlu kist hidatik vakası oldukça nadir olup bizde karaciğer kist hidatiği ile birlikte surrenal kist hidatiği ve çıkan kolona açılım gösteren enfekte kist hidatik vakasını sunduk. Surrenal bez ve sağ kolonik kist hidatik gaz süperpozisyonu gibi hastaya bağlı faktörler veya operatöre bağlı sebeplerden dolayı her zaman ultrasonografi (US) ile saptanamayabilir . Vakamızda multipl hidatik kist ve kist komplikasyonunun tanısı multidedektör bilgisayarlı tomografi (MDBT) ile tanısı konuldu, kolonoskopi ile kistokolonik bağlantı saptandı. MDBT ile hem multipı kist hidatik odaklarını hem de kistokolonik bağlantı komplikasyonunu saptamamız MDBT'nin ayırıcı tanıdaki önemli rolünü ortaya koymaktadır.

Anahtar kelimeler: Kist hidatik, multidetektör bilgisayarlı tomografi, ultrasonografi, kistokolonik bağlantı, kolonoskopi

\section{INTRODUCTION}

Echinococcus granulosus, which causes hydatid cysts, is one of the major health problems in endemic areas. Hydatid disease is very common and is one of the most frequent parasitoses in, in particular, Turkey, India, several South American countries, Africa, and the Middle East countries. In humans, hydatid cysts involve almost all of the organs, and the most commonly affected organs are the liver ( $70 \%$ of cases) and lungs ( $20 \%$ of cases), with other organs' involvement at around $10 \%[1-4]$. The most common complications of hepatic hydatid disease are adjacent organs' compression or perforation into the bile duct and pleura, pericard or cyst infection. Hollow abdominal organ perforation is very rare [5]. The duodenum, stomach and colon have also been reported on in connection with hydatid cysts [6-9].

Ultrasonography (US) and computed tomography (CT) are used as major methods of diagnosis. For differential diagnoses, the use of different methods, such as colonoscopy, may be required. Ruptures to the right colon and secondary infections complicated by hydatid cysts are very rare. In this study, we aim to present a hydatidosis case in the liver, right adrenal region, and hepatic flexura surrounded by the right colon and omentum, which is related to the right colon lumen and detected by US, CT and colonoscopy.

${ }^{1}$ Dicle University Medical Faculty, Department of Radiology, 21280, Diyarbakır, Turkey

${ }^{2}$ Dicle University Medical Faculty, Department of general surgery, 21280, Diyarbakır, Turkey

Correspondence: Bircan Alan,

Dicle University Medical Faculty, Department of Radiology, Diyarbakır, Turkey Email: bircanalan@hotmail.com

Received: 01.04.2016, Accepted: 18.04.2016

Copyright (C JCEI / Journal of Clinical and Experimental Investigations 2016, All rights reserved 


\section{CASE REPORT}

An 80-year-old female patient with right upper quadrant (RUQ) pain, fatigue and nausea was admitted to the emergency room. The patient's physical examination in the right upper quadrant revealed tenderness and a palpable mass. Biochemical and hematological parameters were as follows: WBC: $10.12 \mathrm{~K} / \mu$, Hb: 8.62 g / dL, Hct: 27.11\%, Eos: 0.397 Null, CRP $14.1 \mathrm{mg} / \mathrm{dl}$, Total Ig E, $483 \mathrm{IU} / \mathrm{mL}$, hydatid cyst HA: $1 / 640$. Abdominal US of the liver detected a thickwalled $(54 \times 44 \mathrm{~mm})$ posterior segment of the right lobe and thick septal abdominopelvic cystic lesion. A hydatid cystic lesion with a diameter of $65 \times 51 \mathrm{~mm}$, with many separations by septa, consistent with a type III hydatid cyst lesion, according to Gharbi classification, was detected in the right liver lobe in segment 7 , by MDCT (Figure 1A). Finally, a septal bilobed cystic lesion, with a diameter of $35 \times 25 \mathrm{~mm}$, was detected on the right adrenal gland(Figure 1B). In addition, a hydatid cystic lesion (50x40 $\mathrm{mm}$ in size) was detected at the hepatic flexura surrounded by the right colon and omentum, located between the ascending colon, segment 6 of liver, and the posterior of the gallbladder It was lobulated, septal, and contrast-enhancing with thick walls. In the posterior inferior part of the cystic lesions was detected a lesion abscess with a 48x44 $\mathrm{mm}$ size and which contained air and was adjacent to the colon(cystocolonic communication ) (Figure 1C). In the mesenteric environment, significant pollution and increased density were found. Based on the findings of the MDCT, a colonoscopy was ordered. The colonoscopic examination revealed that cystocolonic communication was present at the hepatic flexura of the right colon (Figure 2). The patient then underwent laparotomy with a midline incision under general anesthesia. A type III hydatid cyst at the liver with a diameter of $6.5 \times 5.5 \mathrm{~cm}$, type I hydatid cyst on the right adrenal gland with a diameter of $3.5 \times 2.5 \mathrm{~cm}$, and a hydatid cyst at the hepatic flexura surrounded by the right colon and omentum were detected by the laparatomy.
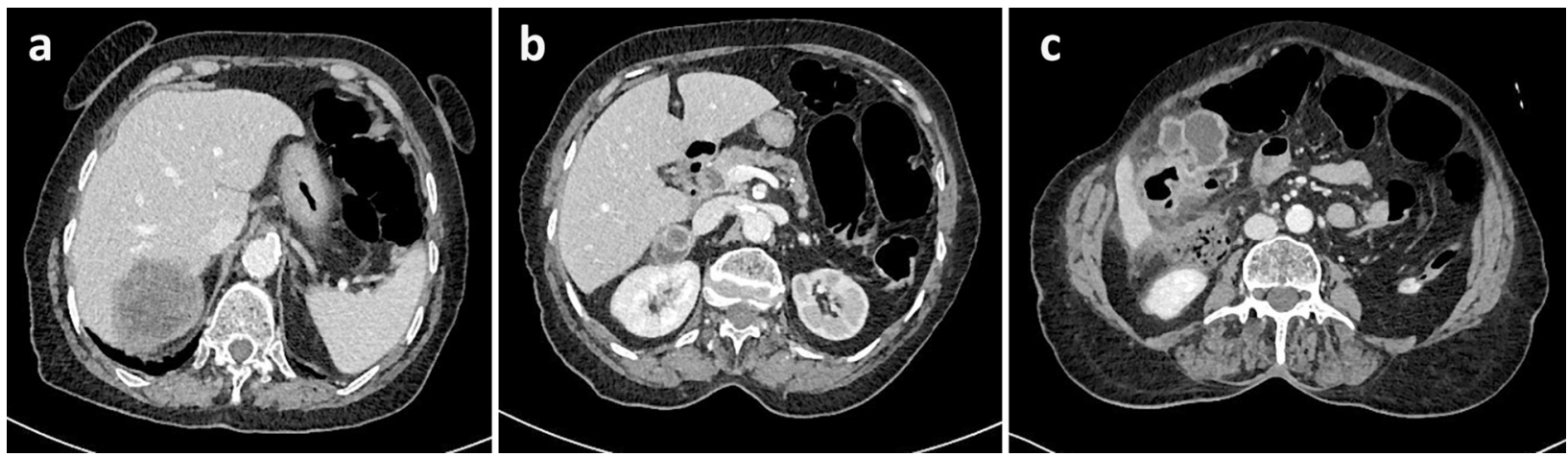

Figure $1 \mathbf{A}$. Abdomen CT scan demonstrating type III hydatid cyst lesion in the right liver lobe in segment 7; 1 B. Abdomen CT scan demonstrating, a septal bilobed hydatid cystic lesion on the right adrenal gland; 1 C. Abdomen CT scan demonstrating a hydatid cystic lesion at the hepatic fleuxura and cystocolonic communication
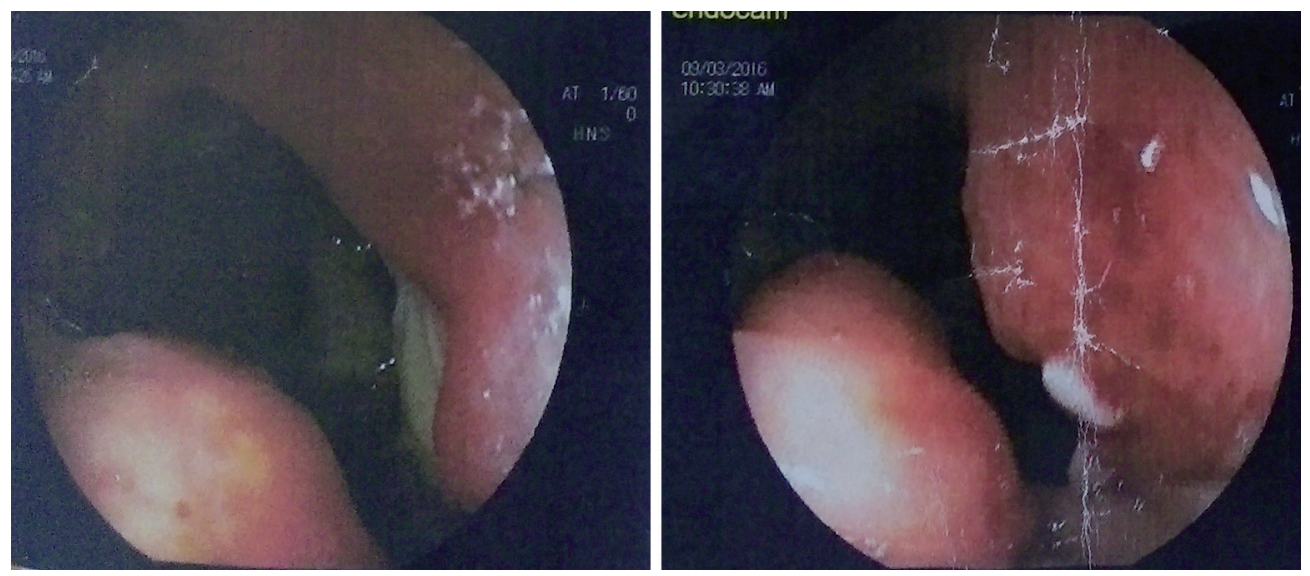

Figure 2. The colonoscopic view of the cystocolonic relation at the right colon arround the hepatic flexura 
The liver hydatid cyst was treated with partial cystectomy and drainage, the adrenal lesion with total cystectomy, and the lesion at the hepatic flexura with right hemicolectomy (Figure 3). $10 \mathrm{mg} / \mathrm{kg} /$ day albendazole was administered preoperatively and continued in the postoperative period. On the 5th postoperative day, a wound infection developed, and the patient was treated with appropriate wound care and antibiotic therapy. The patient was discharged on the $12^{\text {th }}$ postoperative day, with instructions to continue albendazole and call to follow up one month later.

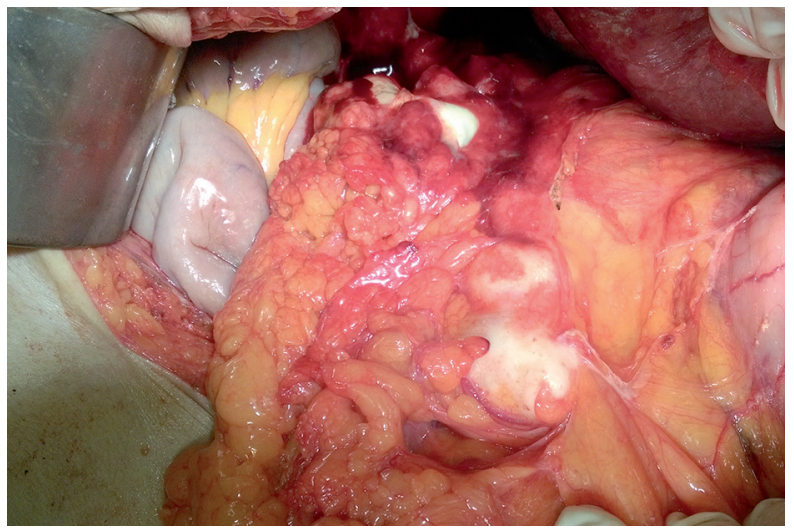

Figure 3. The macroscopic view hydatid cysts at the right surrenal gland and hepatic flexura. The hydatid cyst at the hepatic flexura was surrounded with omentum and right colon and proximal transverse colon

\section{DISCUSSION}

Hydatid disease has a common clinical pathology and is endemic in many parts of the world [10]. The liver is the first filter organ and the most common location for echinococcosis, with lungs being the second. Hydatid cysts show up in other organs in $10-15 \%$ of cases. In addition, echinoccosis may invade the peritoneal cavity and occur in rarer locations via portal circulation and lymphatic ducts, leading to rupture of the gallbladder or primary cysts in peritoneal cavity $[11,12]$. Hydatid cyst rupture may occur in $50-90 \%$ of cases of parasitic membrane degeneration caused by aging, chemical reactions, or defense mechanisms. Rupture into the peritoneal cavity can cause anaphylaxis or new cyst development [13]. In our case, there were three separate focuses related to the rupture of the primary hydatid cysts, which were located at the liver, right adrenal gland, and in the pericolonic area at hepatic flexura. The cyst adjacent to the ascending colon ruptured into the colon and developed cystocolonic connection, and this cyst was infected with intestinal contents.

A case reported by Bougioukas et al. showed the right lobe of the liver's hydatid cyst with perforation into the right colon and an uncomplicated calcified right ovarian cyst, in addition to advanced age in this female patient, characteristics which were similar to our case [9]. In Restivo et al.'s study, a 64-year-old male patient, calcified cysts in segment 4 with a diameter of $6 \mathrm{~cm}$ as a result of migration with hepatic hydatid-colonic fistula associated with development of intestinal obstruction was reported [14]. In our case, the patient presented with a palpable mass in the right upper quadrant with pain, and there was not any intestinal obstruction.

Hydatid disease can be easily recognized preoperatively with radiological examination, such as an US or CT. An ultrasound is used for diagnostic purposes and in the detection of the first plane, particularly cystic membranes, daughter vesicles, septa, and hydatid sand, whereas $\mathrm{CT}$ is the best imaging method for the detection of cyst wall calcification, infection and peritoneal determination. In our case, an intrahepatic cyst was detected by US. Colonoscopy is important for diagnosis of cystocolonic communication and is an essential method for diagnosing the presence of cysts in the colon. Extrahepatic hydatid cysts are rare, especially right pericolonic draining and adrenal hydatid cysts. The differential diagnosis of abdominal cystic lesions, particularly in areas where hydatid cysts are endemic, should be considered in the differential diagnosis.

Declaration of Conflicting Interests: The authors declare that they have no conflict of interest.

Financial Disclosure: No financial support was received.

\section{REFERENCES}

1. Eckert J, Deplazes P. Biological, epidemiological, and clinical aspects of echinococcosis, a zoonosis of increasing concern. Clin Microbiol Rev. 2004;17:107-35.

2. Shukla A, Garge S, Verma P. A case of large renal hydatid cyst. Saudi J Kidney Dis Transpl. 2011 ;22:538-40.

3. Meteroğlu F, Çalışkan A, Şahin A, et al. Atypically located hydatid cyst cases J Clin Exp Invest. 2013;4:352-5.

4. C. Bilgen K, Oner I, OvuI T, Kirazl1. Vertebral hydatid disease presenting as a parapharyngeal and neck mass: a case report. Otolaryngol Head Neck Surg. 126;2002:89-90. 
5. Aday U, Kapan M, Onder O, et al . Liver Hydatid Cyst Associated With Biliary Tract: Is it An Important Complication Indicator? J Curr Surg. 2011;1:25-32.

6. Lo Casto A, Salerno S, Grisanti M, Mastrandrea G. Hydatid cyst of the liver communicating with the left colon. Br J Radiol. 1997;70:650-1.

7. Patankar T, Prasad S, Rohondia OS, et al: Fistulization of hepatic hydatid cyst into duodenum. Indian J Gastroenterol. 1998; 17:152.

8. Noguire M, Alvarez-Castells A, Castella E, et al: Spontaneous duodenal fistula due to hepatic hydatid cyst. Abdom Imaging. 1993;18:234-6.

9. Bougioukas IG, Courcoutsakis N, Korakianitis OS, et al. Liver hydatid cyst perforated into the large bowel: a case report. Cases J. 2009;2:6999.
10. Nadeem N, Khan H, Fatimi S, Ahmad MN. Giant multiple intra-abdominal hydatid cysts. J Ayub Med Coll Abbottabad. 2006;18:71-3.

11. Daali M, Hssaida R, Zoubir Met al. [Peritoneal hydatidosis: a study of 25 cases in Morocco]. Sante. 2000;10:255-60. French.

12. Gollackner B, Längle F, Auer H, et al. Radical surgical therapy of abdominal cystic hydatid disease: factors of recurrence. World J Surg. 2000;24:717-21.

13. Sözüer EM, Ok E, Arslan M. The perforation problem in hydatid disease. Am J Trop Med Hyg. 2002;66:575-7.

14. Restivo A, Zorcolo L, D'Alia G, et al. Colonic obstruction caused by calcified hepatic hydatid cyst migrated into the left colon. Endoscopy. 2010;42:169-70. 